\title{
Improved stratospheric aerosol extinction profiles from SCIAMACHY: validation and sample results
}

\author{
C. von Savigny ${ }^{1}$, F. Ernst ${ }^{2}$, A. Rozanov ${ }^{2}$, R. Hommel ${ }^{2}$, K.-U. Eichmann ${ }^{2}$, V. Rozanov ${ }^{2}$, J. P. Burrows ${ }^{2}$, and \\ L. W. Thomason ${ }^{3}$ \\ ${ }^{1}$ Institute of Physics, Ernst Moritz Arndt University of Greifswald, Felix-Hausdorff-Str. 6, 17489 Greifswald, Germany \\ ${ }^{2}$ Institute of Environmental Physics/Remote Sensing, University of Bremen, Otto-Hahn-Allee 1, 28334 Bremen, Germany \\ ${ }^{3}$ Langley Research Center, National Aeronautics and Space Administration, Hampton, VA 23681, USA \\ Correspondence to: C. von Savigny (csavigny@physik.uni-greifswald.de)
}

Received: 23 June 2015 - Published in Atmos. Meas. Tech. Discuss.: 10 August 2015

Revised: 26 November 2015 - Accepted: 1 December 2015 - Published: 15 December 2015

\begin{abstract}
Stratospheric aerosol extinction profiles have been retrieved from SCIAMACHY/Envisat measurements of limb-scattered solar radiation. The retrieval is an improved version of an algorithm presented earlier. The retrieved aerosol extinction profiles are compared to co-located aerosol profile measurements from the SAGE II solar occultation instrument at a wavelength of $525 \mathrm{~nm}$. Comparisons were carried out with two versions of the SAGE II data set (version 6.2 and the new version 7.0). In a global average sense the SCIAMACHY and the SAGE II version 7.0 extinction profiles agree to within about $10 \%$ for altitudes above $15 \mathrm{~km}$. Larger relative differences (up to $40 \%$ ) are observed at specific latitudes and altitudes. We also find differences between the two SAGE II data versions of up to $40 \%$ for specific latitudes and altitudes, consistent with earlier reports. Sample results on the latitudinal and temporal variability of stratospheric aerosol extinction and optical depth during the SCIAMACHY mission period are presented. The results confirm earlier reports that a series of volcanic eruptions is responsible for the increase in stratospheric aerosol optical depth from 2002 to 2012. Above about an altitude of $28 \mathrm{~km}$, volcanic eruptions are found to have negligible impact in the period 2002-2012.
\end{abstract}

\section{Introduction}

Stratospheric sulfate aerosols mainly comprise $\mathrm{H}_{2} \mathrm{SO}_{4}$ and $\mathrm{H}_{2} \mathrm{O}$, with a $\mathrm{H}_{2} \mathrm{SO}_{4}$ weight percentage of $75 \%$ on average (reviewed by Thomason et al., 2006). The size of the parti- cles depends on the strength of the release of volcanic precursors (mainly $\mathrm{SO}_{2}$ ) in the lower stratosphere and ranges from sub-nanometer molecular clusters, over a few hundred nanometers in the natural stratospheric background (volcanically quiescent periods e.g., Deshler, 2008), up to a few micron in the aftermath of large volcanic injections (e.g., Robock, 2000). Sulfuric acid aerosols are thermodynamically stable in the relatively cold lower stratosphere below about $35 \mathrm{~km}$, forming a global layer - the so-called Junge layer (Junge et al., 1961). The main sources of sulfur for stratospheric sulfate aerosols are thought to be the transport of naturally produced COS (carbonyl sulfide) from the troposphere into the stratosphere, as well as the injection of $\mathrm{SO}_{2}$ and possibly other sulfur compounds into the stratosphere as a consequence of volcanic eruptions. COS, which has natural and anthropogenic sources, is the only sulfur compound with a sufficiently long lifetime to reach the stratosphere (e.g., Warneck, 1988). In the stratosphere COS is oxidized to form $\mathrm{SO}_{2}$, which is then converted to $\mathrm{H}_{2} \mathrm{SO}_{4}$ (Crutzen, 1976). The relative importance of photolysis of COS and its oxidation by $\mathrm{O}$ atoms or excited $\mathrm{O}$ atoms is still not well established. More detailed information on the current understanding of stratospheric sulfur chemistry was presented by Thomason et al. (2006).

Stratospheric aerosols are of fundamental importance for the atmosphere's radiative balance, because they scatter solar radiation, thereby enhancing the Earth's planetary albedo. Particles also contribute to the greenhouse effect, but the warming effect only dominates over the cooling effect for particles with sizes greater than about 2 micron (Lacis et al., 
1992). However, the typical particle sizes for large volcanic eruptions such as the Mount Pinatubo eruption in 1991 are significantly smaller (e.g., Deshler, 2008). After the eruption of Mount Pinatubo, the global mean surface temperature decreased by about $0.4 \mathrm{~K}$ during $1992 / 1993$ in large parts of the world (e.g., Self et al., 1997).

During the last 15 years, the stratospheric aerosol load has exhibited significant variability, including an increase likely caused by a series of volcanic eruptions (e.g., Vernier et al., 2011; Solomon et al., 2011; Neely et al., 2013). Other suggested causes for this increase include enhanced sulfur emissions, e.g., due to coal burning, mainly in China (Hofmann et al., 2009). This suggestion, however, was recently challenged by Neely et al. (2013). The increased stratospheric aerosol load, associated with volcanic eruptions, is also one possible mechanism contributing to the recent global warming hiatus, as suggested by Solomon et al. (2011) and further outlined in IPCC (2013). The CMIP-5 model simulations used for the last IPCC (Intergovernmental Panel on Climate Change) assessment report assume constant stratospheric aerosol after 2000; i.e., they do not consider the changing radiative forcing associated with changes in stratospheric aerosols. An accurate knowledge of the temporal evolution of stratospheric aerosol optical depth and aerosol size is of fundamental importance to the assessment of the role of stratospheric aerosols during the current warming hiatus and also for future climate change.

Stratospheric sulfate aerosols are also of importance for stratospheric chemistry because they may facilitate chlorine activation through heterogeneous reactions (Solomon et al., 1993), and they also act as nucleation nuclei for polar stratospheric clouds that play a crucial role in the formation of the Antarctic ozone hole, as well as catalytic ozone losses within the Arctic polar vortex during cold Arctic winters. Stratospheric aerosols are central to the discussion on geoengineering by solar radiation management (e.g., Crutzen, 2006; Robock, 2008). Any potential testing, either using natural phenomena such as volcanic eruptions, or man made, for such complex management strategies requires precise measurements of stratospheric aerosol.

Measurement techniques employed to study stratospheric aerosol parameters include in situ particle sampling, e.g., by optical means (e.g., Deshler, 2008), single or multiwavelength LIDAR observations (e.g., Jumelet et al., 2008; Hofmann et al., 2009), satellite solar (e.g., Thomason, 1991; McCormick and Veiga, 1992; Lumpe et al., 1997) or stellar (e.g., Vanhellemont et al., 2010) occultation measurements, as well as satellite observations of limb-scattered solar radiation (Bourassa et al., 2007; Taha et al., 2011; Ovigneur et al., 2011; Ernst et al., 2012).

In this article we present validation results for an improved version of the SCIAMACHY limb-scatter stratospheric aerosol extinction profile algorithm, that was developed at the Institute of Environmental Physics at the University of Bremen. In an earlier study Ernst et al. (2012) pre- sented an algorithm description, error budget and validation results for a previous version of the SCIAMACHY stratospheric aerosol retrieval. The new data set presented here is validated with co-located SAGE-II stratospheric aerosol profile measurements. Using different retrievals approaches, Taha et al. (2011) and Ovigneur et al. (2011) also presented stratospheric aerosol profile retrievals from SCIAMACHY limb-scatter observations.

The structure of the paper is as follows. In Sect. 2.1 we provide a description of the SCIAMACHY instrument focusing on the aspects most relevant to this study. In Sect. 2.2 the stratospheric aerosol retrieval algorithm is briefly described, and the differences with the previous version of the aerosol data product are highlighted. A brief description of the SAGE II stratospheric aerosol retrievals is given in Sect. 3. Section 3 presents comparisons of the SCIAMACHY stratospheric aerosol extinction profile retrievals with co-located SAGE II measurements. Sample results are presented in Sect. 5, and conclusions are given at the end.

\section{Stratospheric aerosol extinction profile retrievals from SCIAMACHY limb-scatter measurements}

\subsection{SCIAMACHY on Envisat}

SCIAMACHY, the SCanning Imaging Absorption spectroMeter for Atmospheric CHartography was 1 of 10 scientific instruments on board ESA's Envisat satellite. Envisat was launched on 28 February 2002 from Kourou (French Guiana) into a sun-synchronous orbit having an equator-crossing time of 10:00 a.m. in a descending node. SCIAMACHY is an 8-channel grating spectrograph covering the spectral range from about 220 to $2380 \mathrm{~nm}$ with a wavelength dependent spectral resolution between 0.2 and $1.5 \mathrm{~nm}$. SCIAMACHY nominal operations started in August 2002 and were suddenly interrupted in April 2012 due to a spacecraft failure. During an orbit SCIAMACHY performed observations in alternate nadir and limb viewing geometry and solar/lunar occultation geometry, as well as nighttime limb-emission observations and provided daily measurements of the solar spectral irradiance. A more detailed description of the SCIAMACHY instrument can be found in Burrows et al. (1995), Bovensmann et al. (1999) or Gottwald and Bovensmann (2011). The stratospheric aerosol profile retrievals described in this publication are based on SCIAMACHY limb-scatter observations in the visible spectral range (SCIAMACHY channels 3 and 4). The retrievals are based on SCIAMACHY Level 1 data version 7.0x, and the data were calibrated with all options except flags 0,6 , and 7 corresponding to memory effect correction, polarization correction and absolute calibration, due to the remaining issues with these calibration steps. The aerosol retrieval approach used in this study is insensitive to the absolute radiometric calibration. 


\subsection{Algorithm description}

The algorithm used to retrieve stratospheric aerosol extinction profiles from SCIAMACHY limb-scatter observations has been described in detail by Ernst et al. (2012) and Ernst (2013), and only the most important features are summarized here. The retrieval is based on a color-index approach employing normalized limb-radiance profiles at wavelengths of 470 and $750 \mathrm{~nm}$ following Bourassa et al. (2007). The inverse problem is solved with an iterative optimal estimation approach as described by Ernst (2013). The radiative transfer model SCIATRAN (Rozanov et al., 2014) is run online during the retrieval. The earlier version (version 1.0) described in Ernst et al. (2012) used the HenyeyGreenstein phase function parametrization. This was found to be inadequate for an accurate retrieval of stratospheric aerosol extinction profiles (see also Sect. 3). The current version 1.1 used here is based on scattering phase functions calculated using Mie scattering theory (e.g., Deirmendjian, 1969) assuming aerosol size parameters are representative of stratospheric background conditions, i.e., a mono-modal log-normal aerosol particle size distribution with a median radius of $0.11 \mu \mathrm{m}$ and a distribution width of $\sigma=1.37$ following the in situ balloon observations by Deshler (2008). The value of the Ångstrøm exponent used for the retrievals is $\alpha=\frac{\ln \beta_{750}-\ln \beta_{470}}{\ln 750-\ln 470} \approx-1.434$, with $\beta_{750}$ and $\beta_{470}$ being the aerosol extinction coefficients at 750 and $470 \mathrm{~nm}$. The retrieval uses atmospheric background profiles for the date, time and location of each SCIAMACHY limb measurement from the ECMWF (European Centre for Medium-Range Weather Forecasts) operational analysis. In addition, the seasonally dependent surface albedo climatology by Matthews (1983) is used for the radiative transfer calculations. The sensitivity of version 1.1 stratospheric aerosol extinction profile retrievals from SCIAMACHY limb-scatter observations to errors in the assumed surface albedo was determined recently by Ernst (2013). An albedo error of \pm 0.15 is associated with aerosol extinction changes of $8 \%$ at most for altitudes between 15 and $35 \mathrm{~km}$. The extinction changes are generally below $4 \%$. Ernst (2013) also studied the impact of an optically thick tropospheric cloud layer (optical depth $\tau=20$ ) with $3 \mathrm{~km}$ vertical extent (below the field of view) on the stratospheric aerosols profile retrievals. Except for the highest southern latitudes - associated with scattering angles exceeding $130^{\circ}$ - the impact of clouds was found to be less than about $10 \%$. At the highest southern latitudes retrieval errors of up to $40 \%$ can occur. Future versions of the SCIAMACHY stratospheric aerosol profile retrieval will include an effective albedo retrieval based on the limb radiances near the reference tangent height.

We also point out that assuming a log-normal particle size distribution with constant median radius and distribution width prevents the actual variability of the stratospheric aerosol particle size distribution, associated with for exam- ple seasonal variations, QBO (Quasi-Biennial Oscillation) effects or volcanic eruptions to be taken into account. A future version of the stratospheric aerosol profile retrieval from SCIAMACHY limb observations will be based on extinction profile retrievals at several individual wavelengths. This approach yields simultaneous retrievals of particle size information.

\section{SAGE II aerosol profile retrievals}

The Stratospheric Aerosol and Gas Experiment (SAGE) II was a solar occultation instrument on ERBS (Earth Radiation Budget Satellite) that provided global measurements of stratospheric $\mathrm{O}_{3}$ and $\mathrm{NO}_{2}$ profiles and stratospheric aerosol extinction profiles at different wavelengths in the optical spectral range, including $525 \mathrm{~nm}$. SAGE II operated from 1984 to 2005 and its stratospheric aerosol data set is generally considered to be one of the data sets with the highest accuracy. For this reason it is often used for validation studies and is well suited for comparisons with the SCIAMACHY stratospheric aerosol retrievals presented here.

A new version (7.0) of the SAGE II stratospheric aerosol data set was recently presented by Damadeo et al. (2013), yielding stratospheric aerosol extinction profiles that sometimes differ significantly from the earlier version 6.2. In this study, we use both SAGE II versions for the validation of SCIAMACHY aerosol extinction profile retrievals.

\section{Comparison with SAGE II aerosol extinction profiles}

We start by comparing globally averaged co-locations between SAGE II occultation and SCIAMACHY limb-scatter observations. The co-location criteria are $500 \mathrm{~km}$ spatial distance and $6 \mathrm{~h}$ temporal difference at most between the SAGE II and SCIAMACHY measurements. As a result of the complexity of the radiative transfer in limb geometry at large solar zenith angles (SZAs), SCIAMACHY limb measurements for SZAs exceeding $87^{\circ}$ were not considered. All available co-locations between 1 January 2003 and 17 August 2005 were used. The SAGE II aerosol extinction values at a wavelength of $525 \mathrm{~nm}$ were used, and the SCIAMACHY extinction coefficients were evaluated at this wavelength using the assumed Ångstrøm exponent.

Figure 1 shows a comparison between SAGE II and SCIAMACHY aerosol extinction profiles at $525 \mathrm{~nm}$ for all colocations. The left panel of Fig. 1 depicts the averaged SCIAMACHY (red solid line), SAGE II (version 6.2 shown as black and version 7.0 as blue solid line) profiles, together with the SCIAMACHY a priori profile (green solid line). The dashed colored lines show the corresponding standard deviations. The right panel of Fig. 1 shows the relative difference between the SCIAMACHY and SAGE II profiles relative to SAGE II, i.e., (SCIAMACHY - SAGE)/SAGE for SAGE II versions 6.2 (black solid line) and 7.0 (blue solid line). 

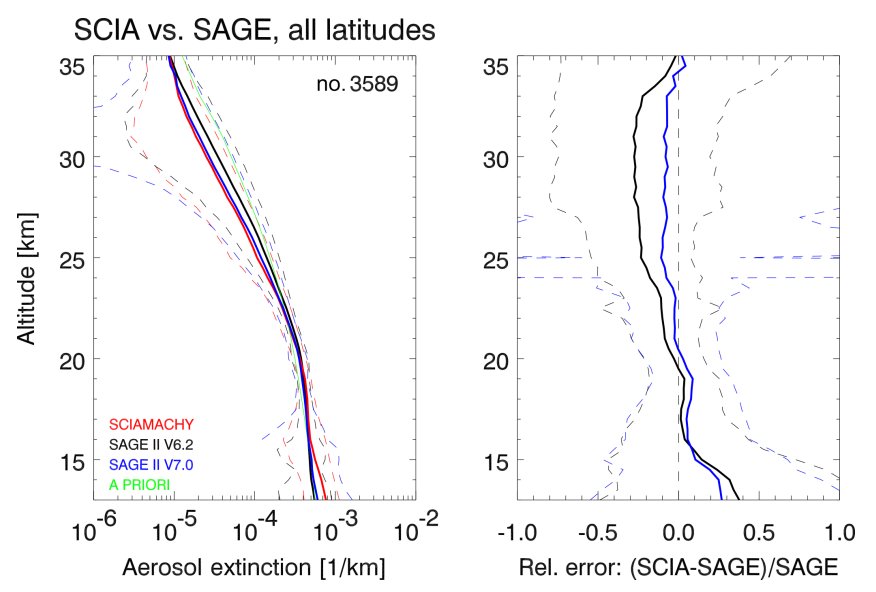

Figure 1. Left panel: comparison of average co-located SAGE II version 6.2 (black solid line) and version 7.0 (blue solid line) and SCIAMACHY version 1.1 (red solid line) aerosol extinction profiles with standard deviation (dashed lines). The green line corresponds to the a priori extinction profile used for the SCIAMACHY retrievals. The number in the top right corner shows the number of co-locations averaged. Right panel: mean relative difference between SCIAMACHY and SAGE II (version 6.2 in black and version 7.0 in blue) aerosol extinction profiles with standard deviation (dashed).

The dashed lines again correspond to the standard deviations of the relative differences. The total number of co-locations used for this comparison is 3589. We find average agreement to within about $10 \%$ between SCIAMACHY and SAGE II version 7.0 aerosol extinction profiles for all altitudes between 15 and $35 \mathrm{~km}$, which can be considered very good. Interestingly, the relative differences between SCIAMACHY and SAGE II version 6.2 are with values of up to about $30 \%$ significantly larger than between SCIAMACHY and the new SAGE II version 7.0. This suggests that in a global average sense, differences between SAGE II version 6.2 and version 7.0 of up to about $20 \%$ have to be expected. This estimate is in good agreement with the direct comparisons between the two SAGE II versions presented by Damadeo et al. (2013).

The good agreement between SCIAMACHY and SAGE II version 7.0 aerosol extinction profiles in the global average is promising, but may not imply similar agreement in different hemispheres or for specific latitude bands. In order to identify possible interhemispheric differences in the agreement with SAGE II measurements, we show in Fig. 2 comparisons between SCIAMACHY and SAGE II stratospheric aerosol extinction at $525 \mathrm{~nm}$ for both hemispheres. The color/line convention is the same as in Fig. 1. SCIAMACHY aerosol extinction profiles are in very good agreement with SAGE II version 7.0 in the Southern Hemisphere (1635 individual co-locations) - with relative differences of less than about $10 \%$ between 16 and $33 \mathrm{~km}$. However, in the Northern Hemisphere (1954 co-locations) the differences reach about $20 \%$ at altitudes above $25 \mathrm{~km}$ with SCIAMACHY aerosol extinction being lower than the SAGE values.

We further refine the comparisons by comparing colocated SCIAMACHY and SAGE II measurements for $20^{\circ}$ latitude bins in Fig. 3. Table 1 lists relative differences between SCIAMACHY and both SAGE II versions for different altitudes and the different latitude bins. Figure 3 shows that there is no constant bias between SCIAMACHY and SAGE II aerosol extinction; the differences vary with latitude and altitude in a complex manner. At tropical latitudes the SCIAMACHY aerosol extinctions are generally lower than the SAGE II values, and the differences between the two SAGE II versions are smaller than for most other latitude bins. In the Northern Hemisphere the differences between SCIAMACHY and SAGE II version 7.0 decrease from low to mid latitudes and increase again at polar latitudes. In the Southern Hemisphere the differences between SCIAMACHY and SAGE II version 7.0 become smaller and change their sign. It is important to point out that some of the observed latitudinal variation of the difference between SAGE II and SCIAMACHY stratospheric aerosol extinction profiles is likely related to differences between the assumed scattering phase function - which is based on the assumed size parameters - and the actual scattering phase function in combination with the latitudinal variation of the scattering angle of the SCIAMACHY limb-scatter observations. The scattering angle varies from about $30^{\circ}$ at high northern latitudes to about $150^{\circ}$ at high southern latitudes. Errors in the assumed scattering phase function can easily lead to differences in retrieved aerosol extinction of several tens of $\%$ and may also lead to significant interhemispheric differences in the aerosol extinction retrieval errors from SCIAMACHY limb-scatter observations (see also Sect. 4.1).

In terms of the agreement between the two SAGE II versions we find that the differences generally increase with increasing altitude and version 7.0 aerosol extinction is almost always smaller than the version 6.2 values. Furthermore, the differences are relatively small at low latitudes, increase towards mid-latitudes - particularly at altitudes above $25 \mathrm{~km}-$ and decrease again at the highest latitudes.

\subsection{Comparison of SCIAMACHY version 1.0 and 1.1 stratospheric aerosol data sets}

As discussed in Sect. 2.2 the previous version (1.0) of the SCIAMACHY stratospheric aerosol data product was based on a Henyey-Greenstein scattering phase function with an asymmetry parameter of $g=0.712$ (Ernst et al., 2012; Ernst, 2013). In contrast, version 1.1 is based on a more realistic Mie phase function, which was implemented to reduce the large interhemispheric differences between SCIAMACHY and co-located SAGE II extinction profiles present in SCIAMACHY version 1.0. Figure 4 shows comparisons between SCIAMACHY and SAGE II aerosol extinction profiles for SCIAMACHY version 1.0 (HG for Henyey-Greenstein) and 

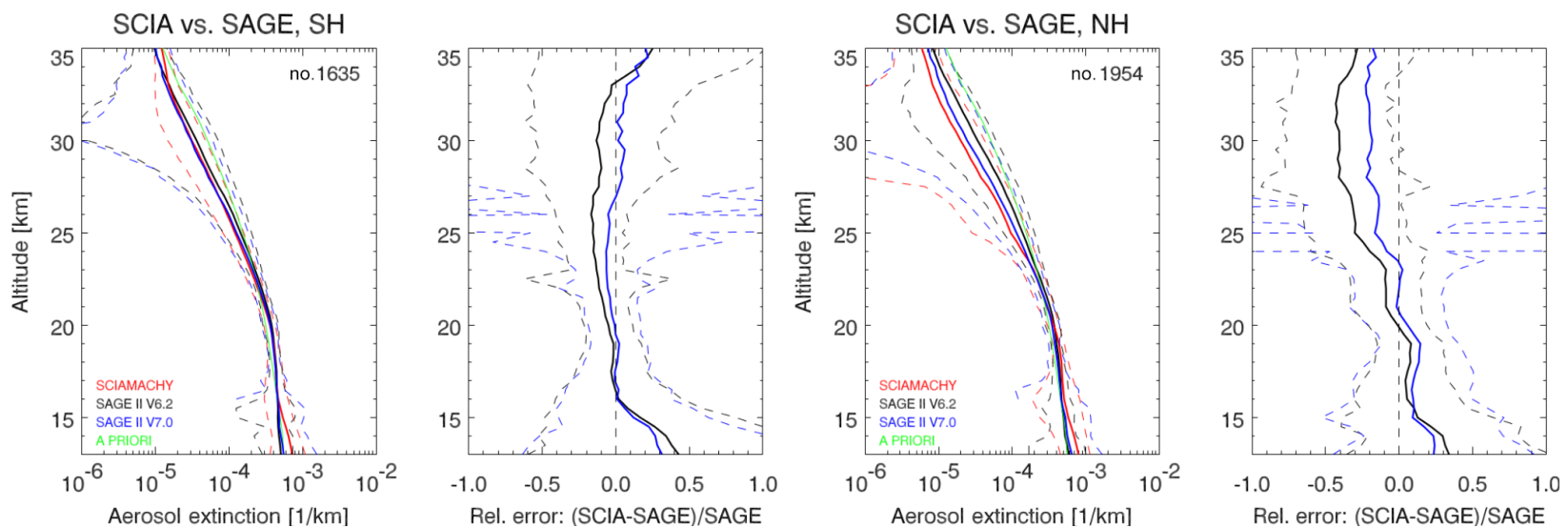

Figure 2. Similar to Fig. 1 but separated into Southern Hemisphere co-locations (left panels) and Northern Hemisphere co-locations (right panels) of SCIAMACHY and SAGE II measurements.

Table 1. Relative difference (\%) of the SCIAMACHY aerosol extinction with respect to co-located SAGE II measurements, both averaged in 8 latitude bins and given in 5- $\%$ steps.

\begin{tabular}{|c|c|c|c|c|c|c|c|c|c|c|c|c|c|c|c|c|}
\hline \multirow{2}{*}{$\begin{array}{l}\text { Alt. }(\mathrm{km}) \\
\text { SAGE II version }\end{array}$} & \multicolumn{2}{|c|}{$60-80^{\circ} \mathrm{N}$} & \multicolumn{2}{|c|}{$40-60^{\circ} \mathrm{N}$} & \multicolumn{2}{|c|}{$20-40^{\circ} \mathrm{N}$} & \multicolumn{2}{|c|}{$0-20^{\circ} \mathrm{N}$} & \multicolumn{2}{|c|}{$0-20^{\circ} \mathrm{S}$} & \multicolumn{2}{|c|}{$20-40^{\circ} \mathrm{S}$} & \multicolumn{2}{|c|}{$40-60^{\circ} \mathrm{S}$} & \multicolumn{2}{|c|}{$60-80^{\circ} \mathrm{S}$} \\
\hline & 6.2 & 7.0 & 6.2 & 7.0 & 6.2 & 7.0 & 6.2 & 7.0 & 6.2 & 7.0 & 6.2 & 7.0 & 6.2 & 7.0 & 6.2 & 7.0 \\
\hline 15 & 10 & 10 & 10 & 10 & (20) & (15) & - & - & - & - & (80) & (70) & 10 & 10 & 5 & 5 \\
\hline 20 & 0 & 5 & 5 & 15 & -10 & -5 & -30 & -30 & -20 & -20 & -5 & -5 & 0 & 5 & -5 & 0 \\
\hline 25 & -40 & -25 & -15 & 0 & -20 & -5 & -25 & -20 & -30 & -20 & -25 & -20 & -15 & -5 & -10 & 0 \\
\hline 30 & -50 & -30 & -35 & 0 & -25 & -5 & -30 & -20 & -40 & -30 & -40 & -25 & -15 & 20 & 25 & 25 \\
\hline Mean & -20 & -10 & -10 & 5 & -15 & 0 & -30 & -25 & -30 & -25 & -20 & -15 & -5 & 10 & 5 & 5 \\
\hline
\end{tabular}

version 1.1 (MIE) with SAGE II version 6.2 (left panels) and SAGE II version 7.0 (right panels) for both hemispheres separately. The comparisons with both SAGE II data versions show that the interhemispheric difference found in SCIAMACHY version 1.0 is significantly smaller in SCIAMACHY version 1.1. For SCIAMACHY version 1.0 the SCIAMACHY stratospheric aerosol extinctions are significantly high-biased in the Southern Hemisphere, compared to the Northern Hemisphere and relative to SAGE II aerosol profiles. The reduction in interhemispheric asymmetry for SCIAMACHY version 1.1 clearly shows that the Mie phase function is a much more adequate aerosol scattering phase functions compared to the Henyey-Greenstein parametrization used for SCIAMACHY version 1.0.

\subsection{Effect of clouds on the SCIAMACHY/SAGE II comparisons}

In order to investigate the effect of clouds on the SCIAMACHY stratospheric aerosol extinction profile retrievals we employ the cloud occurrence data base also obtained from SCIAMACHY limb-scatter observations in the near-IR spectral range using the cloud flagging algorithm SCODA (SCIAMACHY Cloud Detection Algorithm) described by Eichmann et al. $(2009,2015)$. Due to the relatively large geo- graphical footprint of individual SCIAMACHY limb measurements of about $250 \mathrm{~km}$ across viewing direction by about $500 \mathrm{~km}$ in viewing direction the majority of all limb-scatter observations are affected by tropospheric clouds. According to Eichmann et al. (2015) (their Fig. 8b) the annually averaged tropospheric cloud occurrence rate measured with SCIAMACHY limb-scatter observations exceeds $90 \%$ at almost all geo-locations. Using cloud-free SCIAMACHY measurements for the comparison with SAGE II, only 138 out of the total of 3589 co-locations between the two instruments remain. Figure 5 shows the comparison between SCIAMACHY and SAGE II aerosol extinction profiles with the cloud filter applied. Interestingly, the relative differences are very similar compared to the differences shown in Fig. 1 without the cloud filter applied. This implies that any inhomogeneity of the limb-scattered radiance across the field of view of SCIAMACHY is not the major source of the differences.

\section{Sample results}

In this section we present results on the latitudinal and temporal variability of stratospheric aerosol extinction and stratospheric aerosol optical depth. In order to avoid contam- 

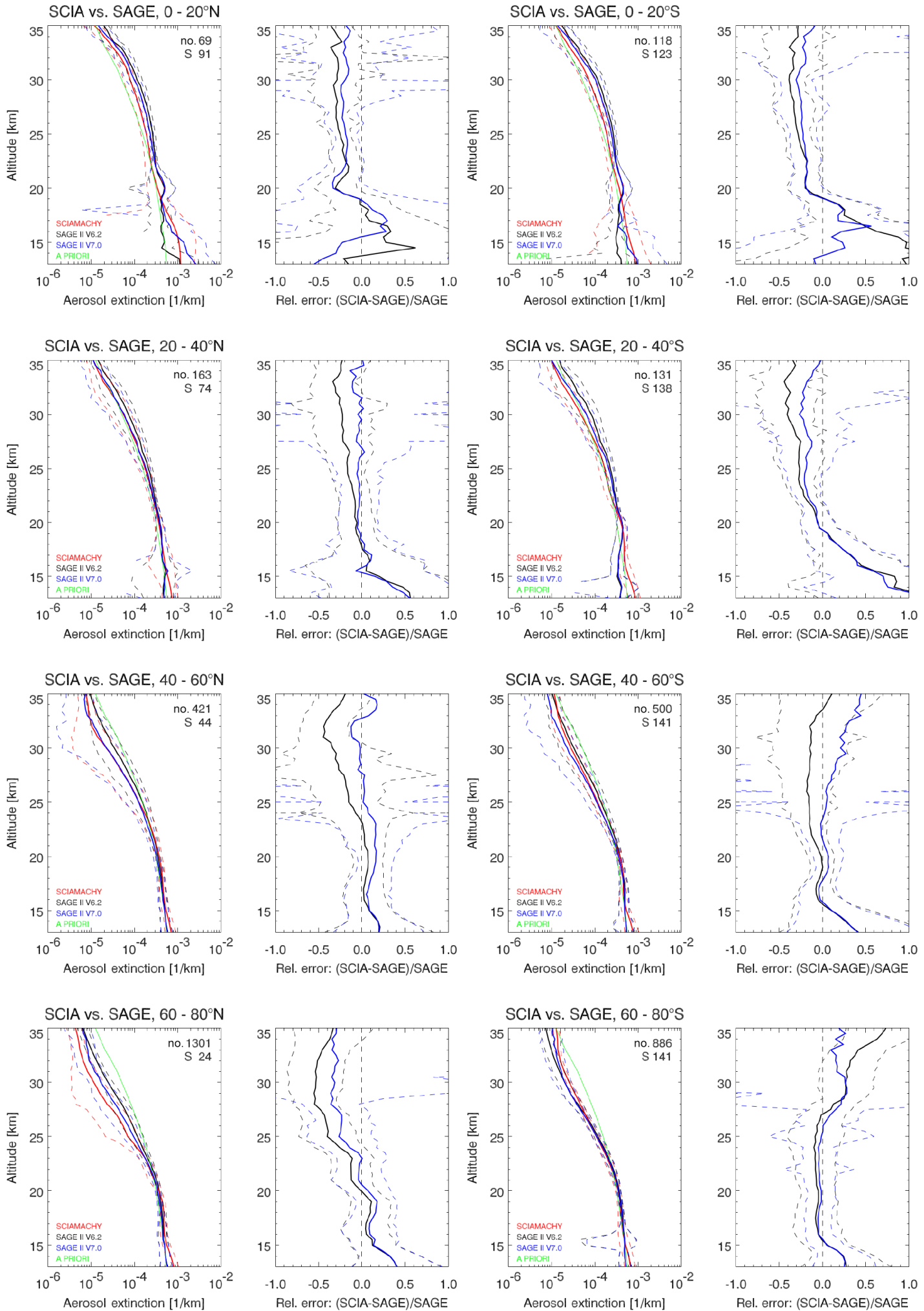

Figure 3. Left panels: comparison of the retrieved SCIAMACHY $525 \mathrm{~nm}$ aerosol extinction profiles (red solid line) with SAGE II version 6.2 (black solid line) and version 7.0 (blue solid line) aerosol extinction for eight latitude bins. The dashed lines show the corresponding standard deviations. The green line again shows the SCIAMACHY a priori profile. The numbers in the top right corner show the number of colocations averaged ("\#") and the average scattering angle (" $S$ ") in degrees. Right panels: mean relative difference between SCIAMACHY and both versions of SAGE II aerosol extinction profiles (solid lines with the same color code as in the left panels) with standard deviations (dashed). 

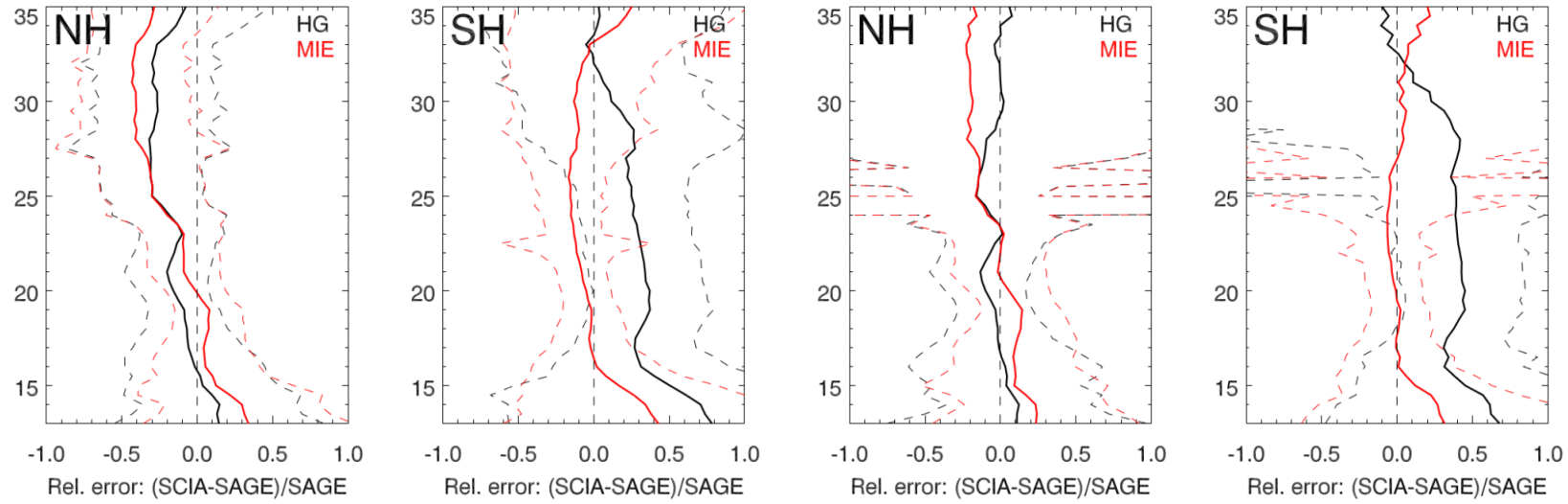

Figure 4. Left panels: comparison between SCIAMACHY version 1.0 (HG) and Version 1.1 (MIE) with SAGE II version 6.2 stratospheric aerosol extinction profiles at $525 \mathrm{~nm}$ for both hemispheres. Right panels: similar to left panels, but for SAGE II version 7.0.

SCIA vs. SAGE, all latitudes
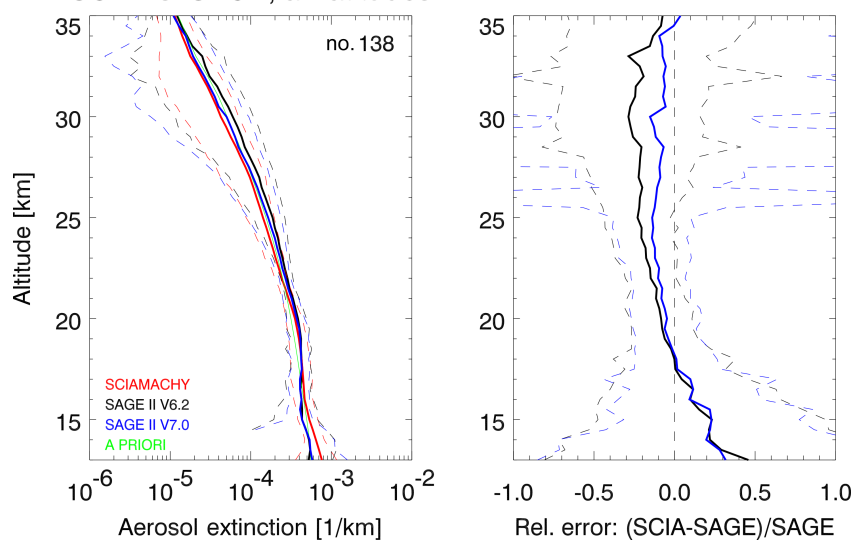

Figure 5. Left panel: comparison of average co-located SAGE II (black and blue) and SCIAMACHY (red) aerosol extinction profiles with standard deviation (dashed lines) for cloud-free SCIAMACHY limb-scatter observations only. The green line shows the a priori extinction profile used for the SCIAMACHY retrievals. The number in the top right corner shows the number of co-locations averaged. Right panel: mean relative difference between SCIAMACHY and SAGE II aerosol extinction profiles with standard deviation (dashed).

ination by tropospheric clouds, which can reach altitudes of up to $16-17 \mathrm{~km}$ at low latitudes, stratospheric aerosol optical depth is determined by integrating the extinction profiles from the $\Theta=380 \mathrm{~K}$ isentrope up to $40 \mathrm{~km}$ altitude, following Bourassa et al. (2010).

Figure 6 shows the retrieved stratospheric aerosol extinction at a wavelength of $525 \mathrm{~nm}$ and at $18 \mathrm{~km}$ (top left panel), $22 \mathrm{~km}$ (top right panel), $26 \mathrm{~km}$ (bottom left panel) and $30 \mathrm{~km}$ (bottom right panel) altitude for the period from 1 January 2003 to 31 December 2011. Note that the aerosol extinction profiles were daily and zonally averaged. The white letters in the top left panel indicate volcanic eruptions (see Fig. cap- tion) and the "Black Saturday" pyrocumulus event in February 2009 (E; e.g., Siddaway and Petelina, 2011). During approximately the first 2.5 years of the SCIAMACHY mission, that were relatively unaffected by volcanic activity, the aerosol extinction at $18 \mathrm{~km}$ shows a pronounced annual cycle at mid-latitudes in both hemispheres with a wintertime maximum, and low values in the tropics and subtropics, where the aerosol layer resides at higher altitudes. This annual variation is consistent with LIDAR measurements of the stratospheric aerosol backscatter ratio observed from Boulder $\left(40^{\circ} \mathrm{N}\right)$ and Hawaii $\left(19^{\circ} \mathrm{N}\right)$ (Barnes and Hofmann, 1997, 2001; Hofmann et al., 2009) and is linked to seasonal variations in stratospheric temperature and moisture as well as the meridional transport associated with the Brewer-Dobson circulation (Hamill et al., 1997; Thomason et al., 2006). The volcanic eruptions lead to significantly enhanced stratospheric aerosol extinction values at $18 \mathrm{~km}$ altitude. The effects of mid and high latitude eruptions - e.g., Kasatochi in August 2008 (e.g., Bitar et al., 2010; Bourassa et al., 2010) and Sarychev Peak in June 2009 (e.g., O'Neill et al., 2012; Kravitz et al., 2011) - are limited to the corresponding hemisphere, but can affect tropical latitudes.

The season during which eruptions occur has a significant impact on the meridional transport of the volcanic aerosol and of pyrocumulus injections into the upper troposphere. The aerosol detected after the Australian Black Saturday bushfires (E in Fig. 6) in winter 2009 was predominantly transported equatorward, whereas the aerosol produced by the Mount Merapi eruption (G in Fig. 6) in fall 2010 was mainly transported poleward.

The aerosol extinction fields at 18 and $22 \mathrm{~km}$ (top panels of Fig. 6) show signatures of polar stratospheric clouds (PSCs) during hemispheric spring, particularly pronounced in the Southern Hemisphere at the highest latitudes during September and October. We have to point out that the SCIAMACHY stratospheric aerosol profile retrieval assumes a Mie phase function characteristic for stratospheric background aerosol, 

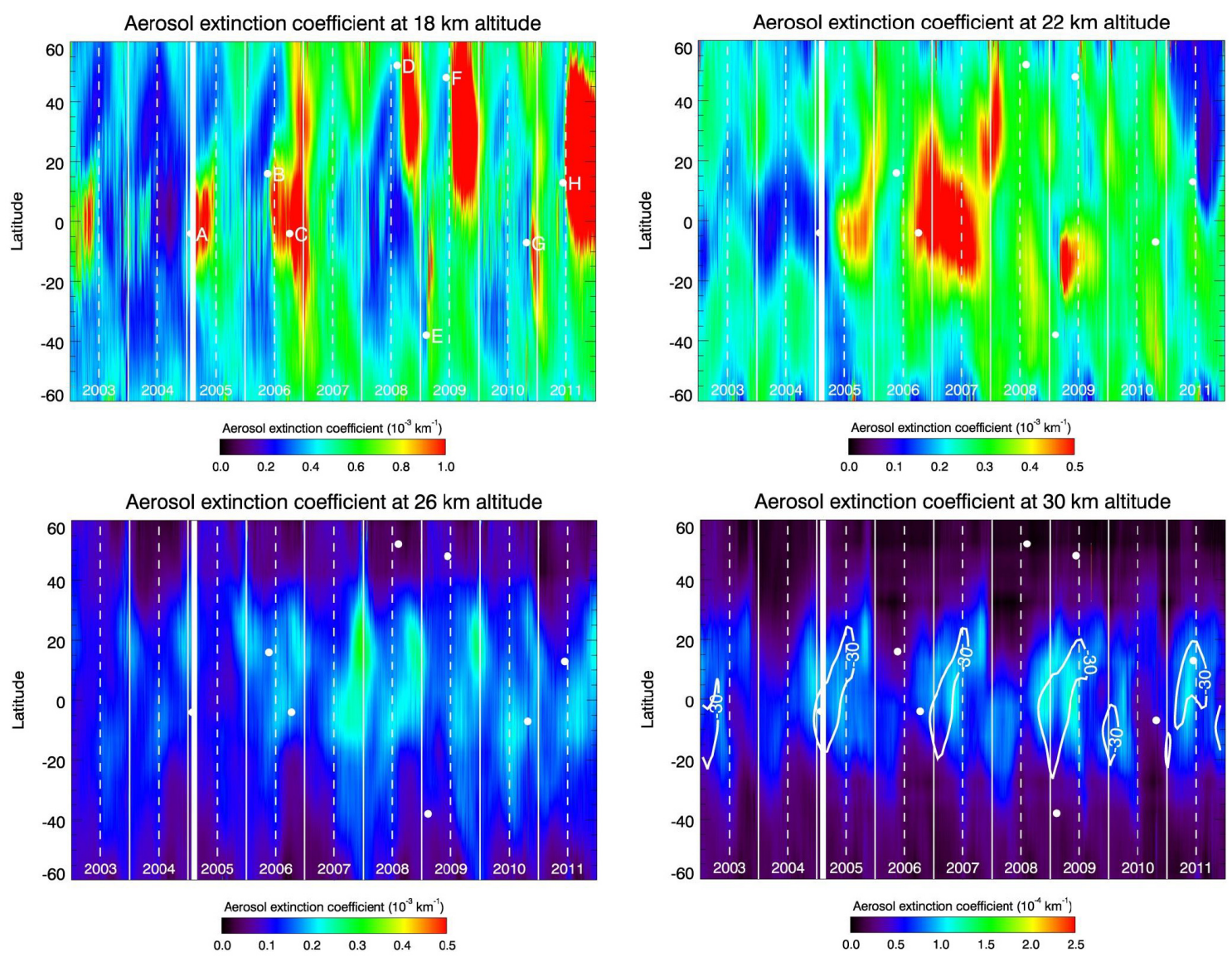

Figure 6. Aerosol extinction coefficient fields at $525 \mathrm{~nm}$ wavelength as a function of time and latitude at $18 \mathrm{~km}$ (top left panel), $22 \mathrm{~km}$ (top right panel), $26 \mathrm{~km}$ (bottom left panel) and $30 \mathrm{~km}$ altitude (bottom right panel). The aerosol extinction profiles were daily and zonally averaged. The capital letters in the top left panel indicate volcanic eruptions (Manam: A, January 2005, $4^{\circ}$ S; Soufriere Hills: B, May 2006, $16^{\circ} \mathrm{N}$; Tavurvur: C, October 2006, $4^{\circ} \mathrm{S}$; Kasatochi: D, August 2008, $52^{\circ} \mathrm{N}$; Sarychev Peak: F, June 2009, $48^{\circ}$ N; Mount Merapi: G, October 2010, $7^{\circ} \mathrm{S}$; Nabro: H, June 2011, $13^{\circ} \mathrm{N}$ ) and the Australian bush fires (E) of February 2009 at $38^{\circ} \mathrm{S}$. The white stripe indicates a gap in the standard limb measurement coverage. The bottom right panel also shows the $-30 \mathrm{~m} \mathrm{~s}^{-1}$ contour line of the monthly and zonally averaged zonal wind at the $10 \mathrm{hPa}$ level taken from ERA Interim.

not for PSCs. The retrieved aerosol extinction for measurements affected by PSCs is therefore only an indicator of their enhanced extinction, and the extinction values may be affected by larger uncertainties than the stratospheric background aerosol retrievals. Whilst type Ib PSC particles are liquid and thus may be well described by Mie theory, type Ia PSC particles, which consist of solid nitric acid trihydrate, $\mathrm{HNO}_{3} \cdot 3 \mathrm{H}_{2} \mathrm{O}$ or NAT and type II PSC particles, which consist of ice, are not spherical particles. More accurate phase functions for NAT and ice are required to obtain accurate extinction profiles.

The impact of the volcanic eruptions decreases with increasing altitude, as expected. At $30 \mathrm{~km}$ (bottom right panel of Fig. 6) a volcanic signature is hardly apparent in the latitudinally resolved time series and the main variability component at low latitudes has a period characteristic of the Quasi-Biennial Oscillation (QBO, reviewed by Baldwin et al., 2001). The enhanced tropical aerosol extinction values at $30 \mathrm{~km}$ altitude occur during easterly shear conditions of the QBO (Trepte and Hitchman, 1992; Hommel et al., 2015). The bottom right panel of Fig. 6 also shows the $-30 \mathrm{~m} \mathrm{~s}^{-1}$ (i.e., easterlies) contour line of the monthly and zonally averaged zonal wind at $10 \mathrm{hPa}$ taken from the ERA Interim reanalysis. The results demonstrate that enhancements in aerosol extinction at $30 \mathrm{~km}$ altitude are linked to strong easterlies at the $10 \mathrm{hPa}$ pressure level. These enhancements in aerosol extinction are caused by an upward motion, which is a manifestation of the QBO secondary oscillation induced by meridional temperature gradients caused by the wave-driven vertical wind shear (Trepte and Hitchman, 1992; Baldwin et al., 2001; Hommel et al., 2015). Brinkhoff et al. (2015) recently discussed the underlying physical mechanisms, also based on SCIAMACHY stratospheric aerosol measurements, in more detail.

The top panel of Fig. 7 shows the latitude and time variation of stratospheric aerosol optical depth (between $\Theta=$ 
(a) Stratospheric aerosol optical depth at $525 \mathrm{~nm}$

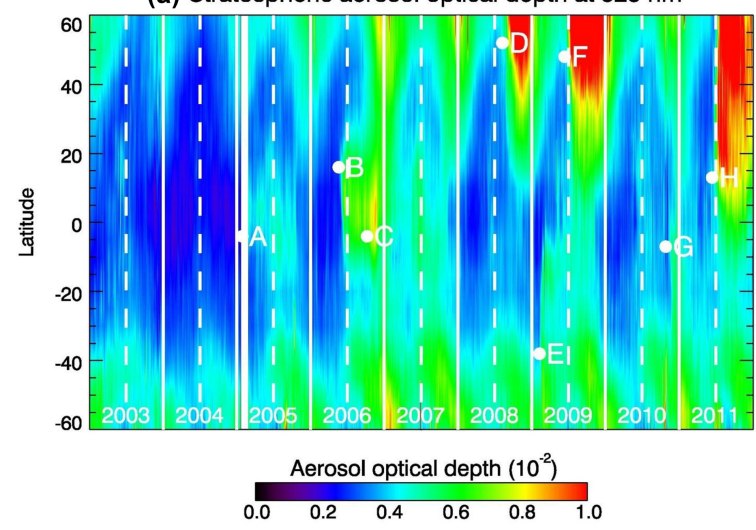

(b) Aerosol OD - weighted average for $\left[60^{\circ} \mathrm{S}, 60^{\circ} \mathrm{N}\right]$

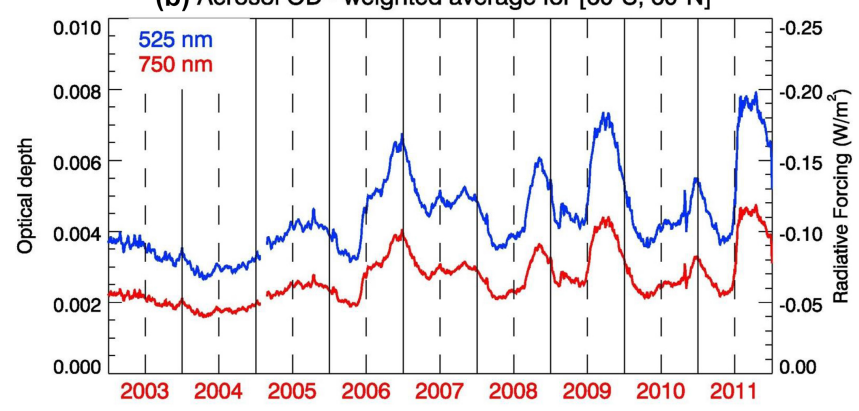

Figure 7. Top panel: stratospheric aerosol optical depth field at $525 \mathrm{~nm}$ wavelength and integrated from the $380 \mathrm{~K}$ isentrope up to $40 \mathrm{~km}$ as a function of time and latitude with daily resolution. The letters indicate the same events as in Fig. 6. Bottom panel: stratospheric aerosol optical depth at 525 and $750 \mathrm{~nm}$ wavelength integrated from the $380 \mathrm{~K}$ isentrope up to $40 \mathrm{~km}$ and corresponding to a surface-area weighted average between $60^{\circ} \mathrm{S}$ and $60^{\circ} \mathrm{N}$ (left ordinate). The right ordinate of the bottom panel shows the stratospheric aerosol radiative forcing determined using the approach discussed by Hansen et al. (2005) as described in the text (Note inverted scale). The right ordinate only applies to the blue line, i.e., $525 \mathrm{~nm}$ wavelength.

$380 \mathrm{~K}$ and $40 \mathrm{~km}$ altitude) at a wavelength of $525 \mathrm{~nm}$. The effects of the volcanic eruptions are again clearly visible and are associated with local enhancements of the aerosol optical depth of up to a factor of about 5 . The bottom panel of Fig. 7 shows the temporal evolution of stratospheric aerosol optical depth averaged over latitude and weighted with the surface area of the latitude bins, from $60^{\circ} \mathrm{S}$ to $60^{\circ} \mathrm{N}$, again for the period 1 January 2003-31 December 2011. The optical depth is shown at wavelengths of 525 and $750 \mathrm{~nm}$, in order to facilitate comparisons with previous studies that present optical depth at different wavelengths. Note that the ratio of the optical depths at these two wavelengths is constant and determined by the fixed Ångstrøm exponent mentioned in Sect. 2.2. In 2003 and 2004 the globally averaged aerosol optical depths are $3-4 \times 10^{-3}$ and around $2 \times 10^{-3}$ at 525 and $750 \mathrm{~nm}$, respectively. The temporal evolution exhibits in- termittent enhancements associated with the volcanic eruptions as evident from the comparisons of the upper and lower panel of Fig. 7. The maximum stratospheric aerosol optical depth values of about $8 \times 10^{-3}$ and $4-5 \times 10^{-3}$ at 525 and $750 \mathrm{~nm}$, respectively, during the time period covered by SCIAMACHY measurements occur in summer 2011 after the eruption of Nabro, and correspond to roughly 2 times the 2003/2004 values. Following Hansen et al. (2005), we can convert stratospheric aerosol optical depth (OD) to radiative forcing (RF) using the formula $\mathrm{RF}=-25 \times \mathrm{OD}(\lambda=$ $525 \mathrm{~nm}$ ), as in Solomon et al. (2011). The right axis of the bottom panel of Fig. 7 shows the radiative forcing caused by the stratospheric aerosol. The radiative forcing varies from about $-0.1 \mathrm{~W} \mathrm{~m}^{-2}$ in $2003 / 2004$ to a peak value of about $-0.2 \mathrm{~W} \mathrm{~m}^{-2}$ immediately after the Nabro eruption in summer 2011. Please note that the radiative forcing shown in the bottom panel of Fig. 7 applies to the optical depth at $525 \mathrm{~nm}$ (blue line).

Similar to the top panel of Fig. 7 we show in Fig. 8 time series of stratospheric aerosol optical depth and radiative forcing for different latitude bins with $20^{\circ}$ meridional extent. For the $20-40^{\circ}$ and $40-60^{\circ}$ latitude bins and during volcanically undisturbed conditions, the winter/spring maximum is clearly visible in both hemispheres. Particularly the low latitudes exhibit significant variability indicating that the stratospheric aerosol layer is highly variable even during periods without major volcanic eruptions (Solomon et al., 2011). This implies that the Brewer-Dobson circulation and the QBO both play an important role for the exchange of COS and any other sources of stratospheric aerosol. The overall increase - with high variability - of the stratospheric aerosol loading during the SCIAMACHY mission period is in good general agreement with the results presented by Solomon et al. (2011).

We now discuss how the stratospheric aerosol optical depths retrieved in this study compare to previously published measurement and model results. The comparison of the stratospheric aerosol optical depth derived from the SCIAMACHY retrievals with earlier results is not straightforward, because different definitions of the stratospheric aerosol optical depth are used in different studies. Brühl et al. (2015) use the $185 \mathrm{hPa}$ pressure level as the lower boundary, Solomon et al. (2011) integrate from 15 to $40 \mathrm{~km}$ altitude, Bourassa et al. (2010) and Kravitz et al. (2011) integrate from the $\Theta=380 \mathrm{~K}$ isentrope up to $40 \mathrm{~km}$ altitude. Moreover, aerosol optical depth is presented at different wavelengths $(530 \mathrm{~nm}$ in Brühl et al. (2015), presumably $525 \mathrm{~nm}$ in Solomon et al. (1993) - this is not explicitly mentioned - and $750 \mathrm{~nm}$ in Bourassa et al. (2010) and Kravitz et al. (2011)) which further complicates direct comparisons. In order to simplify the comparison of our results with these published results we show in Fig. 7 (bottom panel) and Fig. 8 stratospheric aerosol optical depth at two wavelengths (525 and $750 \mathrm{~nm}$ ). 

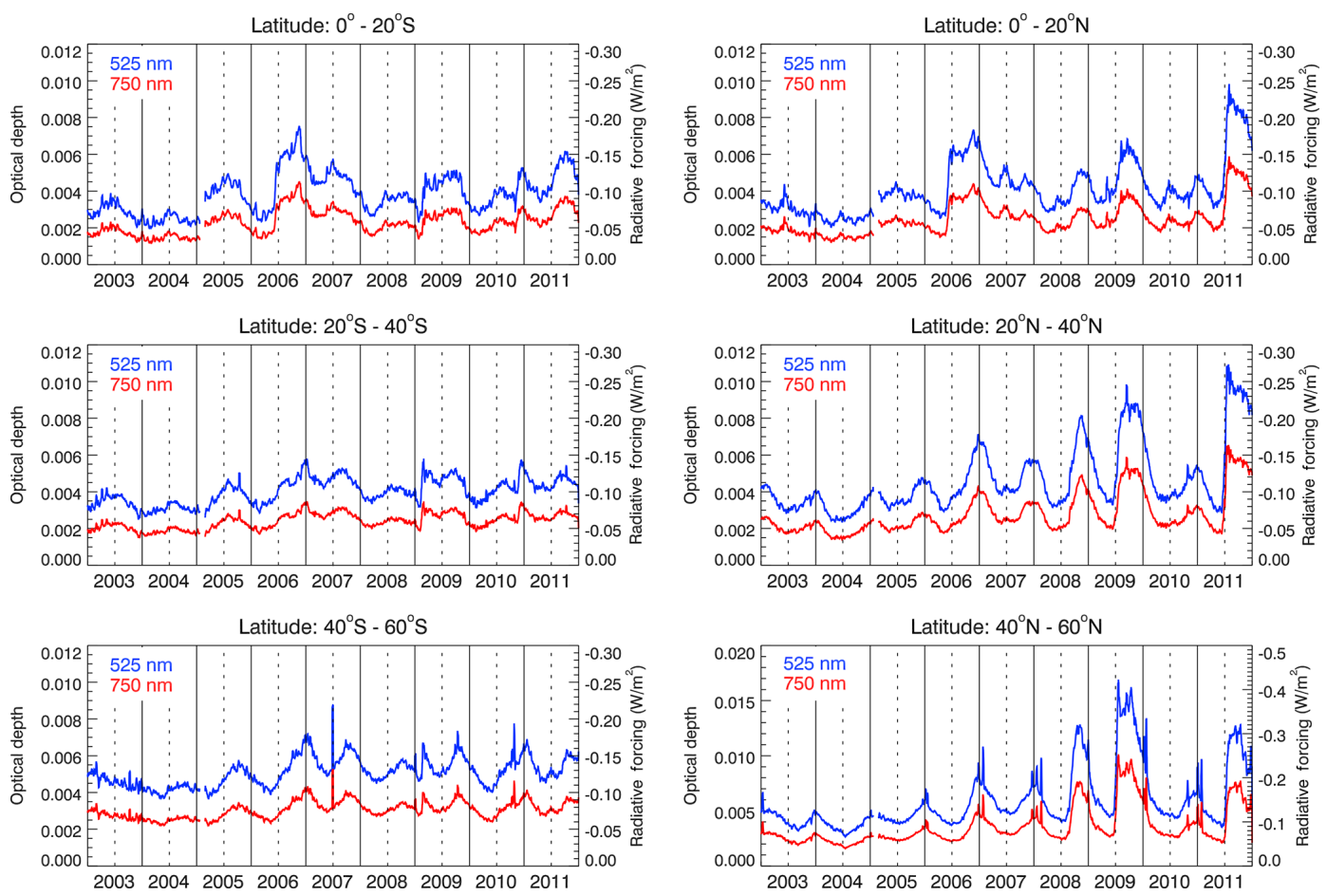

Figure 8. Stratospheric aerosol optical depth (between $380 \mathrm{~K}$ potential temperature and $40 \mathrm{~km}$ altitude) time series at 525 and $750 \mathrm{~nm}$ wavelength for different $20^{\circ}$ latitude bins. Note that the right ordinate only applies to the blue line, i.e., $525 \mathrm{~nm}$ wavelength.

Solomon et al. (2011) show the temporal evolution of stratospheric aerosol optical depth from 1994 to 2010 for the tropics and the $50^{\circ} \mathrm{S}-50^{\circ} \mathrm{N}$ latitude range (their Fig. 2). For 2003/2004 they find values of about $5 \times 10^{-3}$ for both latitude ranges. These values are slightly larger than the $3-$ $4 \times 10^{-3}$ found in our study. The differences may be related to the differences in the lower altitude limit. Brühl et al. (2015) present measurement and model results of stratospheric aerosol optical depth from 2002 to 2011 for the $20^{\circ} \mathrm{S}-20^{\circ} \mathrm{N}$ and the $45-70^{\circ} \mathrm{N}$ latitude ranges (their Fig. 11). For the tropical latitude range optical depths of around $4 \times 10^{-3}$ at $530 \mathrm{~nm}$ are found in 2003/2004 in both the EMAC model results and the SAGE/CALIPSO measurements. These values are in good agreement with the results presented here. The quantitative enhancements in aerosol optical depth due to the volcanic eruptions are slightly different in Brühl et al. (2015) compared to our results, e.g., for the case of the Soufriere Hills and Tavurvur eruptions in 2006, but the overall agreement can be considered good. We can also compare the aerosol optical depth time series for the $45-70^{\circ} \mathrm{N}$ latitude range in Brühl et al. (2015) with the 40$60^{\circ} \mathrm{N}$ results shown in the bottom right panel in Fig. 8. In 2003/2004 Brühl et al. (2015) find values of around $4 \times 10^{-3}$ (at $530 \mathrm{~nm}$ ), which compares well with the $3-5 \times 10^{-3}$ at $525 \mathrm{~nm}$ in our results. Good agreement is also found in terms of the optical depth enhancements associated with the eruptions of Kasatochi, Sarychev Peak, and Nabro.
The Sarychev results presented by Kravitz et al. (2011) allow a comparison of our results with the OSIRIS aerosol optical depth during 2009. During the 2 months prior to the Sarychev eruption Kravitz et al. (2011) report aerosol optical depths of about $3 \times 10^{-3}$ at $750 \mathrm{~nm}$ and latitudes between $50-60^{\circ} \mathrm{N}$ (their Fig. 5, middle panel). The optical depth for this latitude range increases to about $1 \times 10^{-2}$ in August and September. Our results also show optical depths of about $3 \times 10^{-3}$ at $750 \mathrm{~nm}$ and latitudes between $40-60^{\circ} \mathrm{N}$ (bottom right panel of Fig. 8) before the eruption and values of about $1 \times 10^{-2}$ in August and September; i.e., the results presented by Kravitz et al. (2011) are in very good agreement with our results. Similar agreement is found between the Kasatochi results presented by Bourassa et al. (2010) and our results.

In summary, the stratospheric aerosol optical depths presented here are in good quantitative agreement with previously published results in terms of both the relatively quiet conditions in 2003/2004 and the volcanic enhancements that occurred since 2006.

\section{Conclusions}

Stratospheric aerosol extinction profiles in the visible spectral range were retrieved from SCIAMACHY limb-scatter observations using an improved retrieval method. A nearglobal stratospheric aerosol extinction profile data set covering the altitude range from the tropopause up to about $40 \mathrm{~km}$ 
has been retrieved for the period from August 2002 to April 2012. The retrieved aerosol extinction profiles were validated by comparison with co-located solar occultation measurements with SAGE II between January 2003 and the end of the SAGE II mission. A global mean comparison with the latest SAGE II data set (version V7.0) shows agreement within $10 \%$ for altitudes above $15 \mathrm{~km}$. An earlier version of the data set was using a Henyey-Greenstein scattering phase function and showed a strong interhemispheric difference of the comparisons with SAGE II. Comparisons made for different latitude ranges in opposite hemispheres showed that the retrieval improved significantly with the implementation of a Mie scattering phase function based on realistic aerosol particle sizes. We also find relative differences between aerosol extinction coefficients in SAGE II version 6.2 and 7.0 data of up to $40 \%$ for certain altitudes and latitudes. The SCIAMACHY stratospheric aerosol extinction profile data set covers a period characterized by small and medium-sized volcanic eruptions and provides important measurements for the determination of the climate effects of stratospheric aerosol evolution from 2002 to 2012 . Over the period of SCIAMACHY measurements, the changes in aerosol extinction have been shown to be strongly dependent on (a) the volcanic activity up to about $28 \mathrm{~km}$ and (b) dynamical processes, such as the Brewer-Dobson circulation and the quasi biennial oscillation. We find good quantitative agreement of the stratospheric aerosol optical depth derived in this study with previously published results. The radiative forcing of the stratospheric aerosol over the period 2003-2011 has also been assessed. In summary, the SCIAMACHY observations are providing a unique and milestone global record of the stratospheric aerosol between the tropopause and about $40 \mathrm{~km}$ altitude for the period between 2002 and 2012.

Acknowledgements. This work was in part supported by the German Ministry of Education and Research (BMBF) within the project ROMIC-ROSA (grants 01LG1212A and 01LG1212B). This study was made possible by some funding from the ESA SPIN project and the DLR (German Aerospace) funding for SCIAMACHY. Similarly, this study would not have been possible without the base funding of the Institute of Remote Sensing of the University of Bremen and the Institute of Physics of Ernst Moritz Arndt University of Greifswald. SCIAMACHY is jointly funded by Germany, the Netherlands and Belgium. We are also indebted to ESA for providing the SCIAMACHY Level 1 data used in this study.

Edited by: E. Kyrölä

\section{References}

Baldwin M. P., Gray, L. J., Dunkerton, T. J., Hamilton, K., Haynes, P. H., Randel, W. J., Holton, J. R., Alexander, M. J., Hirota, I., Horinouchi, T., Jones, D. B. A., Kinnersley, J. S., Marquardt, C.,
Sato, K., and Takahashi, M.: The quasi-biennial oscillation, Rev. Geophys., 39, 179-229, 2001.

Barnes, J. E. and Hofmann, D. J.: Lidar measurements of stratospheric aerosol over Mauna Loa Observatory, Geophys. Res. Lett., 24, 1923-1926, 1997.

Barnes, J. E. and Hofmann, D. J.: Variability in the stratospheric background aerosol over Mauna Loa Observatory, Geophys. Res. Lett., 28, 2895-2898, 2001.

Bitar, L., Duck, T. J., Kristiansen, N. I., Stohl, A., and Beauchamp, S.: Lidar observations of Kasatochi volcano aerosols in the troposphere and stratosphere, J. Geophys. Res., 115, D00L13, doi:10.1029/2009JD013650, 2010.

Bourassa, A. E., Degenstein, D. A., Gattinger, R. L., and Llewellyn, E. J.: Stratospheric aerosol retrieval with optical spectograph and infrared imaging system limb scatter measurements, J. Geophys. Res., 112, D10217, doi:10.1029/2006JD008079, 2007.

Bourassa, A. E., Degenstein, D. A., Elash, B. J., and Llewellyn, E. J.: Evolution of the stratospheric aerosol enhancement following the eruptions of Okmok and Kasatochi: OdinOSIRIS measurements, J. Geophys. Res., 115, D00L03, doi:10.1029/2009JD013274, 2010.

Bovensmann, H., Burrows, J. P., Buchwitz, M., Frerick, J., Noël, S., Rozanov, V. V., Chance, K. V., and Goede, A. P. H.: SCIAMACHY: Mission objectives and measurement modes, J. Atmos. Sci., 56, 127-150, doi:10.1175/1520 0469(1999)056<0127:SMOAMM>2.0.CO;2, 1999.

Brinkhoff, L. A., Rozanov, A., Hommel, R., von Savigny, C., Ernst, F., Bovensmann, H., and Burrows, J. P.: Ten-year SCIAMACHY Stratospheric Aerosol data record: Signature of the Secondary Meridional Circulation associated with the Quasi-Biennial Oscillation in the Tropical Stratosphere, in: Towards an Interdisciplinary Approach in Earth System Science, edited by: Lohmann, G., Meggers, H., Unnithan, V., Wolf-Gladrow, D., Notholt, J., Bracher, A., Springer Earth System Sciences, Springer International Publishing, Switzerland, 49-58, 2015.

Brühl, C., Lelieveld, J., Tost, H., Höpfner, M., and Glatthor, N.: Stratospheric sulfur and its implications for radiative forcing simulated by the chemistry climate model EMAC, J. Geophys. Res.Atmos., 120, 2103-2118, doi:10.1002/2014JD022430, 2015.

Burrows, J. P., Hölzle, E., Goede, A. P. H., Visser, H., and Fricke, W.: SCIAMACHY - scanning imaging absorption spectrometer for atmospheric chartography, Acta Astronaut., 35, 445-451, doi:10.1016/0094-5765(94)00278-T, 1995.

Crutzen, P. J.: The possible importance of CSO for the sulfate layer of the stratosphere, Geophys. Res. Lett., 3, 73-76, doi:10.1029/GL003i002p00073, 1976.

Crutzen P. J.: Albedo enhancement by stratospheric sulfur injections: a contribution to resolve a policy dilemma?, Climatic Change, 77, 211-219, 2006.

Damadeo, R. P., Zawodny, J. M., Thomason, L. W., and Iyer, N.: SAGE version 7.0 algorithm: application to SAGE II, Atmos. Meas. Tech., 6, 3539-3561, doi:10.5194/amt-6-3539-2013, 2013.

Deshler, T.: A review of global stratospheric aerosol: Measurement, importance, life cycle, and local stratospheric aerosol, Atmos. Res., 90, 223-232, doi:10.1016/j.atmosres.2008.03.016, 2008.

Deirmendjian, D.: Electromagnetic scattering on spherical polydispersions, 290 pp., American Elsevier Pub. Co., New York, ISBN: 978-0444000385, 1969. 
Eichmann, K.-U., von Savigny, C., Reichl, P., Robert, C., Steinwagner, J., Bovensmann, H., and Burrows, J. P.: SCODA: SCIAMACHY ClOud Detection Algorithm from limb radiance measurements, Algorithm Theoretical Baseline Document (ATBD), University of Bremen, Bremen, Germany, 18 pp., 2009.

Eichmann, K.-U., Lelli, L., von Savigny, C., Sembhi, H., and Burrows, J. P.: Global cloud top height retrieval using SCIAMACHY limb spectra: model studies and first results, Atmos. Meas. Tech. Discuss., 8, 8295-8352, doi:10.5194/amtd-8-8295-2015, 2015.

Ernst, F., von Savigny, C., Rozanov, A., Rozanov, V., Eichmann, K.-U., Brinkhoff, L. A., Bovensmann, H., and Burrows, J. P.: Global stratospheric aerosol extinction profile retrievals from SCIAMACHY limb-scatter observations, Atmos. Meas. Tech. Discuss., 5, 5993-6035, doi:10.5194/amtd-5-5993-2012, 2012.

Ernst, F.: Stratospheric aerosol extinction profile retrievals from SCIAMACHY limb-scatter observations, $\mathrm{PhD}$ thesis, University of Bremen, Bremen, Germany, 180 pp., 2013.

Gottwald, M. and Bovensmann, H.: SCIAMACHY - Exploring the Changing Earth's Atmosphere, Springer, Dordrecht Heidelberg London New York, 225 pp., 2011.

Hamill, P., Jensen, E. J., Russel, P. B., und Bauman, J. J.: The life cycle of stratospheric aerosol particles, B. Am. Meteor. Soc., 78, 1395-1410, 1997.

Hansen, J., Sato, M., Ruedy, R., Nazarenko, L., Lacis, A., Schmidt, G. A., Russell, G., Aleinov, I., Bauer, M., Bauer, S., Bell, N., Cairns, B., Canuto, V., Chandler, M., Cheng, Y., Del Genio, A., Faluvegi, G., Fleming, E., Friend, A., Hall, T., Jackman, C., Kelley, M., Kiang, N., Koch, D., Lean, J., Lerner, J., Lo, K., Menon, S., Miller, R., Minnis, P., Novakov, T., Oinas, V., Perlwitz, Ja., Perlwitz, Ju., Rind, D., Romanou, A., Shindell, D., Stone, P., Sun, S., Tausnev, N., Thresher, D., Wielicki, B., Wong, T., Yao, M., and Zhang, S.: Efficacy of climate forcings, J. Geophys. Res., 110, D18104, doi:10.1029/2005JD005776, 2005.

Hofmann, D., Barnes, J., O’Neil, M., Trudeau, M., and Neely, R.: Increase in background stratospheric aerosol observed with lidar at Mauna Loa Observatory and Boulder, Colorado, Geophys. Res. Lett., 36, L15808, doi:10.1029/2009GL039008, 2009.

Hommel, R., Timmreck, C., Giorgetta, M. A., and Graf, H. F.: Quasi-biennial oscillation of the tropical stratospheric aerosol layer, Atmos. Chem. Phys., 15, 5557-5584, doi:10.5194/acp-155557-2015, 2015.

IPCC: Climate Change 2013, The Physical Science Basis, Fifth Assessment Report of the Intergovernmental Panel on Climate Change, available at: http://www.climatechange2013.org/report/ (last access: 26 July 2015), 2013.

Jumelet, J., Bekki, S., David, C., and Keckhut, P.: Statistical estimation of stratospheric particle size distribution by combining optical modelling and lidar scattering measurements, Atmos. Chem. Phys., 8, 5435-5448, doi:10.5194/acp-8-5435-2008, 2008.

Junge, C. E., Changnon, C. W., and Manson, J. E.: Stratospheric aerosols, J. Meteorol., 18, 81-108, doi:10.1175/15200469(1961)018<0081:SA>2.0.CO;2, 1961.

Kravitz, B., Robock, A., Bourassa, A., Deshler, T., Wu, D., Mattis, I., Finger, F., Hoffmann, A., Ritter, C., Bitar, L., Duck, T. J., and Barnes, J. E.: Simulation and observations of stratospheric aerosols from the 2009 Sarychev volcanic eruption, J. Geophys. Res., 116, D18211, doi:10.1029/2010JD015501, 2011.

Lacis, A., Hansen, J., and Sato, M.: Climate forcing by stratospheric aerosols, Geophys. Res. Lett., 19, 1607-1610, 1992.
Lumpe, J. D., Bevilacqua, R. M., Hoppel, K. W., Krigman, S. S., Kriebel, D. L., Randall, C. E., Rusch, D. W., Brogniez, C., Ramananaherosa, R., Shettle, E. P., Olivero, J. J., Lenoble, J., and Pruvost, P.: POAM II Retrieval Algorithm and Error Analysis, J. Geophys. Res., 102, 23593-23614, doi:10.1029/2002JD002137, 1997.

Matthews, E.: Global Vegetation and Land Use: New HighResolution Data Bases for Climate Studies, J. Clim. Appl. Meteor., 22, 474-487, 1983.

McCormick, M. P. and Veiga, R. E.: SAGE II measurements of early Pinatubo aerosols, Geophys. Res. Lett., 19, 155-158, doi:10.1029/91GL02790, 1992.

Neely, R. R. III., Toon, O. B., Solomon, S., Vernier, J.-P., Alvarez, C., English, J. M., Rosenlof, K. H., Mills, M. J., Bardeen, C. G., Daniel, J. S., and Thayer, J. P.: Recent anthropogenic increases in $\mathrm{SO}_{2}$ from Asia have minimal impact on stratospheric aerosol, Geophys. Res. Lett., 40, doi:10.1002/grl.50263, 999-1004, 2013.

O’Neill, N. T., Perro, C., Saha, A., Lesins, G., Duck, T. J., Eloranta, E. W., Nott, G. J., Hoffman, A., Karumudi, M. L., Ritter, C., Bourassa, A., Abboud, I., Carn, S. A., Savastiouk, V.: Properties of Sarychev sulphate aerosols over the Arctic, J. Geophys. Res., 117, D04203, doi:10.1029/2011JD016838, 2012.

Ovigneur, B., Landgraf, J., Snel, R., and Aben, I.: Retrieval of stratospheric aerosol density profiles from SCIAMACHY limb radiance measurements in the $\mathrm{O}_{2}$ A-band, Atmos. Meas. Tech., 4, 2359-2373, doi:10.5194/amt-4-2359-2011, 2011.

Robock, A.: Volcanic eruptions and climate, Rev. Geophys., 38, 191-219, 2000.

Robock, A.: 20 reasons why geoengineering may be a bad idea, Bull. of the atomic scientists, 64, 14-18, 2008.

Rozanov, V. V., Rozanov, A. V., Kokhanovsky, A. A., and Burrows, J. P.: Radiative transfer through terrestrial atmosphere and ocean: Software package SCIATRAN, J. Quant. Spect. Rad. Trans., 133, 13-71, doi:10.1016/j.jqsrt.2013.07.004, 2014.

Self, S., Zhao, J.-X., Holasek, R. E., Torres, R. C., and King, A. J.: The Atmospheric Impact of the 1991 Mount Pinatubo Eruption, in: Fire and Mud: Eruptions and Lahars of Mount Pinatubo, Philippines, edited by: Newhall, C. G. and Punongbayan, R. S., University of Washington Press, Washington, 1126 pp., 1997.

Siddaway, J. M. and Petelina, S. V.: Transport and evolution of the 2009 Australian Black Saturday bushfire smoke in the lower stratosphere observed by OSIRIS on Odin, J. Geophys. Res., 116, D06203, doi:10.1029/2010JD015162, 2011.

Solomon, S., Sanders, R. W., Garcia, R. R., and Keys, J. G.: Increased chlorine dioxide over Antarctica caused by volcanic aerosols from Mount Pinatubo, Nature, 363, 245-248, doi:10.1038/363245a0, 1993.

Solomon, S., Daniel, J. S., Neely III, R. R., Vernier, J.-P., Dutton, E. G., and Thomason, L. W.: The Persistently Variable "Background" Stratospheric Aerosol Layer and Global Climate Change, Science, 333, 866-870, doi:10.1126/science.1206027, 2011.

Taha, G., Rault, D. F., Loughman, R. P., Bourassa, A. E., and von Savigny, C.: SCIAMACHY stratospheric aerosol extinction profile retrieval using the OMPS/LP algorithm, Atmos. Meas. Tech., 4, 547-556, doi:10.5194/amt-4-547-2011, 2011.

Thomason, L. W.: A diagnostic stratospheric aerosol size distribution inferred from SAGE II measurements, J. Geophys. Res., 96, 22501-22508, doi:10.1029/91JD02521, 1991. 
Thomason, L. W., Peter, T., Carslaw, K. S., Kärcher, B., Notholt, J., Bingemer, H., Hamill, P., Brogniez, C., Deshler, T., AndersonSprecher, R., Weisenstein, D., and Bekki, S.: SPARC Assessment of Stratospheric Aerosol Particles, World Climate Research Programme (WCRP) SPARC Project Report (4), 1-320, 2006.

Trepte, C. R. and Hitchman, M. H.: Tropical stratospheric circulation deduced from satellite aerosol data, Nature, 355, 626-628, 1992.

Vanhellemont, F., Fussen, D., Mateshvili, N., Tétard, C., Bingen, C., Dekemper, E., Loodts, N., Kyrölä, E., Sofieva, V., Tamminen, J., Hauchecorne, A., Bertaux, J.-L., Dalaudier, F., Blanot, L., Fanton d'Andon, O., Barrot, G., Guirlet, M., Fehr, T., and Saavedra, L.: Optical extinction by upper tropospheric/stratospheric aerosols and clouds: GOMOS observations for the period 20022008, Atmos. Chem. Phys., 10, 7997-8009, doi:10.5194/acp-107997-2010, 2010.
Vernier, J.-P., Thomason, L. W., Pommereau, J.-P., Bourassa, A., Pelon, J., Garnier, A., Hauchecorne, A., Blanot, L., Trepte, C., Degenstein, D., and Vargas, F.: Major influence of tropical volcanic eruptions on the stratospheric aerosol layer during the last decade, Geophys. Res. Lett., 38, L12807, doi:10.1029/2011GL047563, 2011.

Warneck, P., Chemistry of the Natural Atmosphere, International Geophysics Series, Vol. 41, 757 pp., Academic Press, San Diego, 1988. 